\section{César Ades}

César Ades (1943-2012) foi um dos maiores psicólogos brasileiros, reconhecido por sua inegável contribuição para o desenvolvimento da profissão no Brasil. A Etologia, ciência que estuda o comportamento animal, era sua principal linha de pesquisa. Ades investigou o comportamento animal e tratou cientificamente da questão dos modos de viver e de agir de várias espécies.

O psicólogo nasceu no Egito, cidade do Cairo, em 18 de janeiro de 1943, e chegou ao Brasil aos 15 anos de idade. Graduou-se em Psicologia, em 1965, no Instituto de Psicologia da USP, realizou seus estudos de mestrado e doutorado em Psicologia Experimental, livre-docência, e assumiu o cargo de professor titular em 1994.

Foi diretor do Instituto de Psicologia da USP entre 2000 e 2004 e vice-diretor no período de 1998 a 2000. Em 2004, ingressou no conselho deliberativo do Instituto de Estudos Avançados (IEA). Em 2007, foi nomeado diretor do IEA para o mandato de fevereiro de 2008 a janeiro de 2012. Também participou do conselho deliberativo do Hospital Universitário da USP e do Conselho Curador da Fundação Universitária para o Vestibular (Fuvest). Era membro da Academia Paulista de Psicologia, ocupando a Cadeira número 19.

No campo profissional, era editor da Revista de Etologia, membro do conselho editorial das revistas Behavior and Philosophy e Acta Ethologica. Integrava o Conselho Internacional de Etólogos, a Sociedade Internacional de Psicologia Comparada e a Sociedade Brasileira de Etologia (SBEt), da qual foi fundador e vice-diretor de 2008 a 2010.

Os estudos recentes de Ades versavam sobre o papel social e o valor estratégico da atividade de psicólogo. Em 2011, organizou evento no Instituto de Estudos Avançados da Universidade de São Paulo (IEA-USP) sobre perspectivas futuras para a Psicologia e mesa sobre esse assunto no III Congresso Brasileiro de Psicologia: Ciência e Profissão, em 2010.

Na visão de César Ades, a Psicologia estava deixando de ressaltar o comum, que, para ele, constituía o cerne psicológico. "Como nos dividimos em escolas, isso nos deixa sem uma linguagem integrada, e mais, sem uma posição integrada em relação à sociedade. A graça da Psicologia é ser assim diversa, não quero que haja uma única linguagem, mas ela precisa encontrar uma proposta unificada dentro da diversidade", pontuou durante entrevista à edição de 30 anos da revista Psicologia: Ciência e Profissão.

Em dezembro de 2010, César Ades falou sobre as mudanças ocorridas na atividade de psicólogo: "Fico impressionado de ver a expansão da área. Há uma nova consciência psicológica, e o número de psicólogos condiciona progressos na pesquisa, na compreensão, na atuação social".

César Ades foi vítima de acidente, em 2012, falecendo aos 69 anos. Sem dúvida, foi um profissional que, inegavelmente, construiu parte da história da Psicologia brasileira. 